\title{
Keeping up the momentum
}

\author{
The International Day of Light is an achievement that the entire photonics community can be proud of. Let's be \\ inspired by the celebrations to begin planning for next year's event.
}

$\mathrm{B}$ uilding on the success of the International Year of Light 2015 (IYL2015), the International Day of Light (IDL) was proclaimed at the 39th session of the General Conference of the United Nations Educational, Scientific and Cultural Organization (UNESCO) on 13 November 2017 to provide an annual focal point to celebrate the importance of light and light-based technologies in our lives. The date chosen for the IDL is 16 May because it coincides with the anniversary of the invention of the first ruby laser by Theodore Maiman in 1960.

"The recognition of an International Day of Light is even more remarkable than the International Year of Light in 2015. We now have the opportunity to mobilize every year under a high-visibility UNESCO banner to promote the importance of our field and its direct relevance to society in areas such as education, energy, climate change, healthcare and communications," said John Dudley from the University of FrancheComté, France, who was the Steering Committee Chair of IYL2015 and now the Steering Committee Chair of IDL2018.

This year, on 16 May, over 600 attendees flocked to the UNESCO building in Paris to attend the inauguration ceremony for the IDL. The ceremony kicked off with a breathtaking musical performance, followed by an inauguration address by the DirectorGeneral of UNESCO, Audrey Azoulay, who stressed that light had had a significant impact on the visual and performing arts, literature and human thinking, and that it could also aid in achieving the Sustainable Development Goals (http://www.undp. org/content/undp/en/home/sustainabledevelopment-goals.html) set out in the United Nations 2030 Agenda for Sustainable Development.

The ceremony was filled with a mixture of talks and presentations, including two talks by Nobel Laureates, two panel discussions on perceptions of light and science policy, and several presentations on international cooperation such as the Synchrotron-Light for Experimental Science and Applications in the Middle East (SESAME) and the European Organization for Nuclear Research (CERN) facilities. Young researchers from Brussels Photonics put on an entertaining performance,

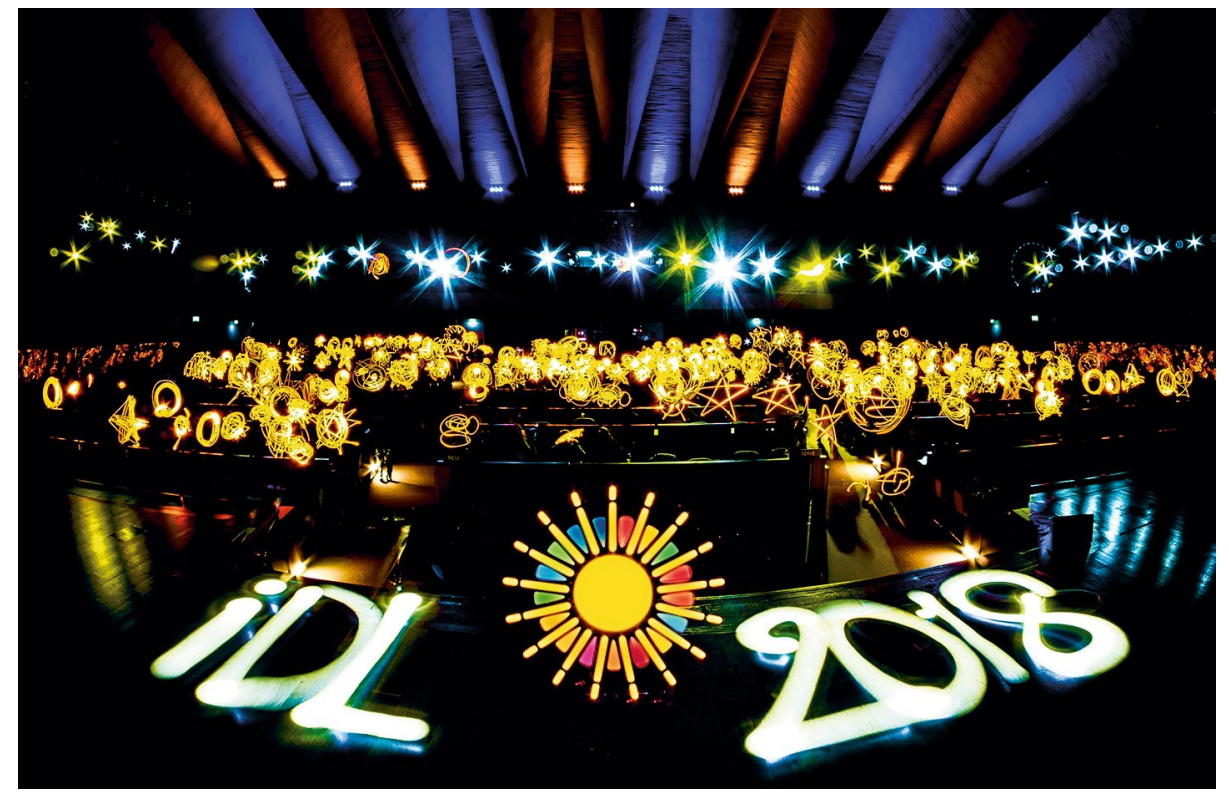

A full list of credits can be found at http://lpwa.pro/event/106.

showcasing the importance and applications of light. Light artists also presented a spectacular light show and took a striking group photo (pictured). The ceremony ended memorably with a light show on the UNESCO building at dusk.

It was also an honour to have Kathleen Maiman, the wife of Theodore Maiman, present at the ceremony. "I think that 16 May is the most fitting date of the year for celebrating the IDL. Before 16 May 1960, there was no laser, there was no coherent light, and only the wayward efforts of many researchers and labs to achieve that end. After Ted's success on 16 May and in the following years, many other types of lasers have been developed. So, clearly, 16 May is a critical date in the history of the laser and the history of mankind," Maiman told Nature Photonics.

To celebrate the IDL, editors at Nature Research couldn't be busier. On 9 May, the editors took part in an event at King's College London to celebrate the launch of the London Institute for Advanced Light Technologies (http://london-light.org), a virtual institute uniting scientists and industries working on emerging photonics technologies in London, to coincide with the celebrations for the IDL. On 15 May, during an outreach event co-organized with University College London, the editors invited young students to play with optical elements for polarization, diffraction and reflection. The event attracted about 240 lively $11-13$ year olds. On 16 May, the Nature Research Berlin Office held an evening event featuring art on display, elevator pitches by five $\mathrm{PhD}$ students from Berlin institutions and a public lecture reviewing laser science and laser applications. Nature Research editors also ran a month-long blog with a series of light-related posts in May on 'On your wavelength' (http://blogs.nature.com/ onyourwavelength), a physics blog from Nature journals.

Overall, there were 640 events held in 88 countries celebrating IDL2018. "As we immerse ourselves in the many celebrations around the world, let's start thinking about plans for next year," urged Dudley. To find out more about what's coming next year and to post your events for 2019, visit the official website of the IDL at www.lightday.org.

Published online: 28 June 2018 https://doi.org/10.1038/s41566-018-0215-3 